\title{
Drivers of Philanthropic Foundations in Emerging Markets: Family, Values and Spirituality
}

\author{
Valeria Giacomin ${ }^{1} \cdot$ Geoffrey Jones ${ }^{2}$
}

Received: 14 August 2020 / Accepted: 14 June 2021 / Published online: 28 June 2021

(c) The Author(s) 2021

\begin{abstract}
This article discusses the ethics and drivers of philanthropic foundations in emerging markets. A foundation organizes assets to invest in philanthropic initiatives. Previous scholarship has largely focused on developed countries, especially the United States, and has questioned the ethics behind the activities of foundations, particularly for strategic motives that served wider corporate purposes. We argue that philanthropic foundations in emerging markets have distinctive characteristics that merit separate examination. We scrutinize the ethics behind the longitudinal activity of such foundations using 70 oral history interviews with business leaders in 18 countries in Africa, Asia, Latin America, and the Middle East. We find that 55 out of 70 foundations associated with these leaders have been used as vehicles for a specific type of philanthropic ethics defined as "spiritual philanthropy". These foundations often embodied personal or family traditions, culture, and religious values, which emphasized charitable giving and social responsibility. As in the case of many of the industrial foundations in Europe, these foundations also carried founding family names and provided a structure to maintain family control and enhance corporate reputation. We argue that, as business leaders in emerging markets are more directly exposed to dire social, educational and health deprivation than their counterparts in developed countries, they are less inclined toward grandiose world-making, and their foundations are more focused on delivering immediate benefits to communities in their home countries, motivated by implicit or explicit spirituality.
\end{abstract}

Keywords Foundations $\cdot$ Philanthropy $\cdot$ Emerging markets $\cdot$ Business leaders $\cdot$ Spirituality

\section{Introduction}

Philanthropic foundations are an important and growing phenomenon, yet our understanding of their philanthropic pursuits and geographic context remains partial. There is a need to investigate better the ethics and motivations that drive the philanthropic foundations in emerging markets. This article addresses this gap. We introduce the concept of spiritual philanthropy (hereafter SP), a new type of entrepreneurial ethics that captures the motives behind many foundations in these contexts.

Valeria Giacomin

valeria.giacomin@unibocconi.it

Geoffrey Jones

gjones@hbs.edu

1 Department of Social and Political Sciences, Bocconi University, Via Röntgen 1, 20136 Milan, MI, Italy

2 Isidor Straus Professor of Business History, Harvard Business School, Soldiers Field, Boston, MA 02163, USA
Foundations have been investigated as one of the most common vehicles of philanthropy. Most of the research on them employs empirical data from developed countries, occasionally supported by data from a few emerging countries. The scholarship on the topic remains scattered across disciplinary fields (Jung et al., 2018; Prewitt et al., 2006; Toepler, 2018). Most studies on foundations have been carried out within the broader research on corporate philanthropy, which in turn is heavily focused on the experience of the United States and other Western countries (Hammack \& Anheier, 2010; Roza et al., 2020; Zunz, 2014).

A major exception is the work of Anheier and Toepler (1999), who created a cohesive and systematic analysis of the nature, purpose, and role of foundations in a crossnational perspective, as well as differences in regulatory frameworks. However, even this research provides only limited insights on foundations in emerging markets and concentrates on trends at the institutional level without delving into the histories of these foundations, their local development or their founders' motivations. According to a World 
Bank estimate, in 2007 fewer than one percent of the world's 100,000 foundations conducted activities related to developing countries (World Bank, 2007). In general, gathering data on foundation activity outside the United States and Europe is hard. However, there are some case studies beyond the West, mainly concerning large emerging and transition economies (Chan \& Lai, 2018; He \& Wang, 2020; Jansons, 2015; Krasnopolskaya, 2020) or regions (Rey-Garcia et al., 2020; Sanborn \& Portocarrero, 2005). This work generally addresses contemporary developments, without broaching the long-term relationship between entrepreneurs, their foundations, and the local business environment. This is a serious gap because, as this article and other research demonstrate, there is a long history of foundations established by business leaders in the emerging world (Cantegreil et al., 2013; Giacomin et al., 2019).

In this article, we aim to understand the drivers behind the activities of foundations across Africa, South and Southeast Asia, the Middle East, and Latin America, through a multilevel approach based on individuals and organizations and their long-term development (Liket \& Simaens, 2015). The analysis concentrates on the motives of business leaders rather than discussing the social role of corporations within capitalism, as in the Corporate Social Responsibility (CSR) literature.

We believe that the concept of SP provides an explanation for the creation and operation of many philanthropic foundations in the emerging world. We define SP as the entrepreneurial ethics inspiring multi-generational philanthropic initiatives and strategies reflecting a responsible approach to capitalism. This includes values driven by spiritual beliefs, religious principles, cultural norms, and local tradition. In emerging markets, SP historically encouraged a level of empathy that resulted in the pursuit of developmental objectives. It promoted primarily, but not exclusively, projects that addressed institutional voids in education, healthcare, and the development of local communities.

We investigated the concept of SP through an abductive approach of reiteration between empirical data and theory (Dubois \& Gadde, 2002). We focused on a subset of 70 oral history interviews with high-profile business leaders operating foundations in 18 emerging countries. The interviews were drawn from a larger database assembled by the Creating Emerging Markets (hereafter CEM) oral history project at the Harvard Business School. We concentrated on their ethical approach and on the role that their foundations have historically played in their local context. We also engaged in a comparative study of SP across these geographies based on how articulated and detailed business leaders were about the ethics behind their foundations' activities.

In our analysis, we followed Roza et al.'s definition of foundations as (i) separate legal entities; with (ii) a social purpose; and (iii) established or (even partially) funded by a for-profit entity (2020, p. 7). Thus, we considered "foundations" as those registered institutions (foundations or trusts) as well as independent large-scale NGOs connected either to the family or to the companies, although sometimes the two may overlap.

In our sample, these included large-scale institutions registered as NGOs and organizations that either represented side activity to for-profit operations or were established after a career in for-profit organizations. We excluded CSR departments connected with the interviewees' companies, NGOs detached from previous or on-going business activity, short-term tenures on the boards of non-family foundations, isolated philanthropic initiatives, and unstructured donations.

The article comprises six main sections. Following this introduction, the second section reviews the literature on the historical drivers and ethics of foundations globally. Section three introduces the empirical material for this study, our oral history methodology and the research design. In section four, we present the findings of our analysis, and then we discuss them in section five. The last section concludes and draws avenues for further research.

\section{Foundations and Ethics of Philanthropy}

\section{A Brief History of Foundations}

Organized charitable giving has been widespread throughout the world for centuries (Nielsen, 1972, p. 3). Foundations spread as formalized institutions in the United States during the nineteenth century, especially because of growing wealth, and the unequal distribution of such wealth, following the Civil War (Gardner, 1992; Wren, 1983). Before the 1940s, some wealthy American business leaders, including Andrew Carnegie and J.D. Rockefeller, established foundations to channel vast sums of money into large-scale and well-organized philanthropic ventures, designed to outlive them (Harvey et al., 2011; O'Connor, 1996; Van Slyck, 1995; Zunz, 2014). In his essay "Wealth" (1889), Carnegie was among the first business leaders to theorize about the need for the wealthy to give back to society. Carnegie established his foundation in 1905, which was then chartered in the following year, starting a process of professionalization of philanthropy that has continued until today (Zunz, 2014, p. 22).

Carnegie's foundation marked the beginning of a common model for organizing philanthropy in the United States, referred here as the "purely philanthropic foundation" (henceforth PPF). These were large-scale organizations almost completely independent from the founder's for-profit business. Facilitated by major tax advantages after legislation allowing deductions from federal income tax in 1917, 
they grew over time to become complex institutions with large endowments that exercised a major impact on American society and education system (Berman, 1983; Duquette, 2019). In the neo-liberal era from the 1980s, there was another surge of PPFs in the United States often correlated with soaring wealth inequality. Tech-entrepreneurs, including Bill Gates and his wife Melinda, Mark Zuckerberg and Priscilla Chan, launched extremely well-funded foundations focused on tackling grand challenges on a global scale (i.e., climate change, pandemics, poverty). They focused on promoting new technologies and the production of specialized knowledge (O'Toole, 2019).

While PPFs were found extensively in the United States, a different type of foundation was more evident in Western Europe which Mayer (2019, p. 40) called the "industrial foundation" (henceforth IF). These were sometimes the result of bequests from the founders of corporations. Examples include the Hans Wilsdorf Foundation in Switzerland, created in 1945 by Hans Wilsdorf, the founder of Rolex; and the Robert Bosch Stiftung in Germany, established in 1964 following the will of the industrialist Robert Bosch. Prominent business families also created them, like the Carlsbergs in 1876 in Denmark and the Wallenbergs in 1918 in Sweden.

IFs differed from PPFs in terms of purpose and impact. Although operating as independent entities, they often maintained strong ties with their founding family and corporations in terms of vision, underlying values, and strategic objectives. They operated on a smaller scale and engaged in projects directed at their country's advancement, like Carlsberg, which primarily focuses on Danish society. These institutions frequently controlled the business assets of the founders, as well as engaging in philanthropy. This is the case of Bosch (Roza et al., 2020, p. 6), which held 92 percent of Robert Bosch GmbH's capital stock of $€ 1.2$ billion in 2020 .

IFs of this kind are also found in emerging markets (WINGS Report, 2018; UNDP, 2016). They are often closely intertwined with business families operating philanthropy in their country for several generations. For instance, two of the Indian Tata philanthropic trusts (Sir Dorabji Tata Trust and Sir Ratan Tata Trust) are endowed and supervised by members of the Tata Family and hold over 60 percent of the highly diversified Tata Group. Like most of the Europeanbased IFs, those in emerging markets remain domestically focused, even though some of the largest founding firmslike Tata and Godrej-are multinationals with extensive operations in both developed and emerging markets.

Mayer, citing examples in Europe and also Tata, praised companies connected to IFs as promoting a positive form of capitalism (2019, pp. 40-41). His argument was that these corporations aligned with founders' values and purpose permitting long-term vision; they had "stronger reputations and sounder labor relations, and high survival rates" (2019, p.
122); and they served "public and social as well as private purposes" (2019, p. 162). In this article, we extend the analysis to emerging markets, where we historicize the concept of foundations and the ethics of their founders.

The fact that IFs became more widespread in Europe (Anheier \& Toepler, 1999; Schuyt et al., 2018), while the PPF model was prominent in the United States, does not make them mutually exclusive. The Leverhulme Trust, one of the biggest British foundations created in 1925 by William Lever, the founder of Lever Brothers (later Unilever), and the Volkswagen Foundation are examples of PPFs that completely detached from their original company. Similarly, a new wave of PPFs arose in recent years in many emerging and transition countries, including India (Cantegreil et al., 2013) and China (Chan \& Lai, 2018). In the case of India, a new generation of high net-worth business leaders established foundations imitating the experience of American billionaires (Jansons, 2015, p. 1001).

\section{The Ethics of Philanthropy in Foundations}

Philanthropic initiatives are often well received by the public and may generate goodwill for business leaders (Hammack $\&$ Anheier, 2010). Philanthropy by family businesses and the operations of (primarily) industrial foundations in the West have been connected to positive social outcomes (Campopiano \& De Massis, 2015; Maung et al., 2020).

However, the activity of PPFs, primarily based on evidence from the United States, has been subject to criticism (Eisenberg, 2005; Faber \& McCarthy, 2005; Roelofs, 2007; Shaw et al., 2013). Nielsen's classic study defined this model of foundations as "undemocratic institutions indulged, even privileged within democracies" (1972, p. 399). More recently, some writers have been explicitly critiquing philanthropic foundations for being the product of severe income inequality (Giridharadas, 2018). Their activity has been labeled as "philanthro-capitalism" (Berman, 1983; Roelofs, 2015) and "ethically flawed" (Harvey et al., 2021 p. 47) for capitalizing on self-interest as a motive of giving. "Philanthro-capitalist" institutions are also accused of failing to question the increasing concentration of wealth (Jensen, 2013; Mcgoey, 2012, p. 197). Additional skepticism is related to how foundations are regulated. While there are significant differences in legal frameworks, most Western countries also privilege foundations with different forms of tax cuts and fiscal incentives. In the United States, they enjoy minimal regulatory control on their internal structure and on the use of their resources (Hammack \& Anheier, 2010).

Other work points to the ethics of business leaders behind foundations, often accused of using tax revenues to shape the socio-political space through these institutions (Hay \& Muller, 2014; Werbel \& Carter, 2002). In a recent study focusing 
on Britain, Harvey et al. (2021) contributed to bridging this gap by synthetizing how philanthropists explained the rationale of their giving. They distinguished two categories of entrepreneurial ethics: "entrepreneurial" (henceforth EP) and "customary" (henceforth CP) philanthropy. The authors do not discuss foundations themselves, but it seems reasonable to assert that EP aligns more closely with the activity of PPFs in pursuing transformational social goals while remaining loyal to the corporate mandate of profit maximization. CP broadly reflects the IF model as it aims at tempering social inequalities through traditional and localized charity, albeit without questioning the inherent inequality produced by capitalism.

Unlike PPFs, the ethics of IFs have attracted much less attention. A few studies have criticized IFs in Southern Europe, Latin America (Pedrini \& Minciullo, 2011), China (He \& Wang, 2020), and India (Raianu, 2016). The main criticism has been an alleged lack of transparency, which allowed them to hide wrongdoing and potential conflicts of interest. IFs were accused of protecting incumbent managers and serving paternalistic interests of their founders and of excluding other stakeholders in the decisions over the use of resources and activities. Founders were criticized for employing foundations primarily as strategic tools to maintain control over corporate assets and enhance their reputation rather than engaging in impactful initiatives (Werbel \& Carter, 2002; Westhues \& Einwiller, 2006).

\section{Foundations and Corporate Giving in Emerging Economies}

While research on local foundations in emerging markets is limited, a more developed scholarship in strategic management, business ethics, and international business has investigated the ethical ramifications of CSR in these settings, providing insights on the contextual differences of emerging countries. The presence of institutional voids and large informal sectors in many countries has been seen as a constraint on the effectiveness and transparency of philanthropy and CSR (Blowfield \& Frynas, 2005; Muthuri \& Gilbert, 2011; Zhao, 2012). It has been suggested that corporate giving needs strong institutions to function properly, and hence companies from emerging markets show even less transparency and accountability than their Western counterparts (Azmat \& Samaratunge, 2009).

This body of research only partially addresses the activities of local actors (Jamali \& Mirshak, 2007; Jamali et al., 2017a). It concentrates on the operations of Western multinationals (MNEs) (Jamali, 2010; Mukherjee, 2016; Shirodkar et al., 2018) and the ethics of their giving (Jamali, 2007; Jamali \& Sidani, 2011; Van Cranenburgh \& Arenas, 2014). One of the few studies looking specifically at CSR through foundations found that, to enhance their reputations, foreign
MNEs gave more in countries with weaker institutional environments and were more likely to partner with international agencies to do so (Hornstein \& Zhao, 2018).

Most critical work on the motivations and ethics of giving has concentrated on corporate CSR in Western settings (Kourula \& Delalieux, 2016). Little research has yet been done on the motivations behind foundation-based philanthropy in emerging markets and its long-term impact in a cross-country perspective. Again, scholarship concentrated on CSR, and the findings are mixed. Elements of convergence from the Western CSR model coexist with elements of divergence (Jamali et al., 2017b). While the language and organizational structure of CSR are developed in line with global standards, normative values seem to drive these initiatives more than strategic motives in emerging countries (Amaeshi et al., 2006). However, local companies are more likely to survive and overcome institutional voids, if they develop a strong reputation (Gao et al., 2017), suggesting that proactive reputation-building drives philanthropic activities also domestically.

Other studies stress isomorphic behaviors both at the international and at the local level. Companies from emerging markets are known to have established CSR departments or foundations to build credibility with potential foreign partners such as multinationals (Amaeshi et al., 2006; Jamali et al., 2011). Thus, CSR might work as a "fad" if local MNEs introduced it from scratch in a cosmetic way to emulate the action of foreign companies operating in their country. Alternatively, CSR vocabulary may be simply applied to traditional philanthropic activities (Jamali, 2010). There is also evidence of local isomorphism, with domestic business groups establishing foundations imitating the steps, structure, and strategies of prominent and wellknown business families, like Koç in Turkey and Tata in India (Giacomin et al., 2019).

In sum, the debate on the ethics of giving in emerging markets has seldom encompassed the work of foundations.

\section{Spiritual Philanthropy in Emerging Markets}

In some emerging markets, institutionalized giving long preceded the trend initiated by figures such as Carnegie and Rockefeller in the United States. This often reflected longestablished religious and cultural norms. In South Asia, for example, monetary contributions for societal causes were a longstanding practice in Hinduism (Krishnan, 2005; Sundar, 2013). In the Islamic world, there was the institution of the Waqf (endowed trusts or foundations) and the practice of Zakat, one of the Five Pillars of Islam, which mandated a customary contribution of 2.5 percent on the value of all possessions for individuals with holdings over a certain threshold (Cizakca, 1998). During the twentieth century and increasingly after WWII, emerging markets also received 
donations from overseas diasporas, often through dedicated foundations. This is especially the case of China and India (Young \& Shih, 2004).

In general, though, most foundation-based activities developed independently from external influences and remained tightly linked with the donors' main corporate activities. In Latin America and Asia, philanthropic foundations emerged from family business groups frequently dating back to the nineteenth century and even earlier, which gained local prominence over subsequent generations (Bhatnagar et al., 2020; Chakrabarty, 2012; Jones \& Comunale, 2018; Rey-Garcia et al., 2020). These families often contributed to the welfare of their community of origin, regions, and countries and simply switched to more formalized foundations in response to new laws.

Due to such longstanding tradition, and because most large business groups in emerging countries relied on protected domestic markets, especially between the 1960s and the 1980s (Austin et al., 2017), foundations developed organically and with distinctive characteristics especially as compared with PPFs. Through their repetitive activity in their countries of origin, they became vehicles representing the values and ethics of their donors, in a broadly similar pattern as seen with IFs in Europe. In this fashion, businesses closely tied the family name to companies' philanthropic activities. This enhanced reputations and legitimacy in their communities (Astrachan et al., 2020; Worden, 2003). Family businesses employed their foundations as a shield to preserve their value system and legacy and to maintain control over their growing operations across generations or as they accessed external capital (Debiki et al., 2016).

Findings on the ethics of family business are mixed. Research focusing mainly on the developed world has argued family-owned businesses might pursue a more ethical behavior than public companies (Cruz et al., 2014; Dieleman \& Koning, 2020). Their longer-term horizon would allow for a more patient attitude toward dividends and longstanding social impact (Sharma \& Sharma, 2019). Some research suggests that this might also be true in the emerging world (Yusof et al., 2014), despite rich anecdotal evidence of corruption from many prominent business families (Caussat, 2017).

In many emerging markets, religion and traditional culture permeate not only the government and public life but also the business world and affiliated institutions (Fathallah et al., 2020; Hackett et al., 2012). As a result, foundation activity is often tightly interwoven with the promotion of national culture and the development of local communities (Kavas et al., 2020). The salience of these values and mentality promotes empathetic responses to the dire conditions business leaders witness in their everyday lives. Especially in South Asia and Sub-Saharan Africa, interviewees are more directly exposed to extreme poverty and the lack of education, healthcare, and infrastructure.

Emerging markets of course, display variation in foundation drivers due to local culture and the contextual perception of philanthropy (Ostrower, 1997). Despite some potential differences, the countries in our sample presented a common denominator as individual beliefs and life philosophies were rooted in the identity of these leaders, building their organizational culture and recurrent behaviors through generations, including their philanthropy (Abdelgawad \& Zahra, 2020).

This evidence suggests that foundations in emerging markets may not fit into Harvey et al.'s (2021) categories of ethics of philanthropy, despite playing a similar role in their communities of reference and benefitting from the high income inequality. Thus, we argue that $\mathrm{EP}$ and $\mathrm{CP}$ do not sufficiently capture the motivations of founders in these settings. We explore the hypothesis that the introduction of SP is required to capture how local business leaders think of their foundations' purpose and strategies in these contexts. Table 1 includes a comparison between EP, CP, and SP.

SP overlaps with the modalities observed in Harvey's study of the ethics of philanthropy, but it also differs significantly. First, SP is generally, but not exclusively, connected with the operations of IFs and specifically of family businesses, stretching across multiple generations and displaying a patient approach to financial returns (Mayer, 2019, p. 40).

Second, it is strongly linked with specific value systems or religious principles, which reflect in the nature and type of partnerships—often involving local religious institutions, government agencies for social services, or other organizations working for civil society and advancing specific goals, i.e., women empowerment or micro-entrepreneurship. However, as the rich literature on spirituality showed (Phipps, 2012; Poole, 2009), formal religious beliefs are only one dimension of the broader spirituality, which is defined as "the desire to find ultimate meaning and purpose in one's life and to live an integrated life" (Phipps, 2012, p. 179). Thus, spirituality extends beyond values and religious beliefs to include decisions, activities, and outcomes.

Third, because it happens in settings affected by extreme inequality, the spiritual background of founders reflects into developmental objectives and trial-and-error strategies. It addresses chronic failures in the provision of public services such as education and health, social infrastructure, and overall institutional frailty. Projects are selected according to local needs and urgency. They are managed through an immediate solution-driven approach.

In the case of PPFs driven by EP, investment is often carefully quantified, projects are planned according to grand and transformational goals, and results and impact are monitored using conventional metrics. In the case of (mainly industrial) foundations driven by SP in emerging markets 
Table 1 Models of ethics of philanthropy

\begin{tabular}{|c|c|c|c|}
\hline & \multicolumn{3}{|l|}{ Philanthropic ethics } \\
\hline & Customary & Entrepreneurial & Spiritual \\
\hline Definition & $\begin{array}{l}\text { Care through benevolence, satisfying } \\
\text { obligations of beneficence by showing } \\
\text { adequate concern for others. It prizes } \\
\text { social cohesion while tolerating the con- } \\
\text { tinued existence of inequalities }\end{array}$ & $\begin{array}{l}\text { Well-conceived, sustainable } \\
\text { social projects that create } \\
\text { opportunities for upward } \\
\text { social mobility }\end{array}$ & $\begin{array}{l}\text { Multi-generational initiatives aimed } \\
\text { at relieving institutional voids in } \\
\text { education and health and addressing } \\
\text { the interest of multiple stakeholders. } \\
\text { Philanthropy inspired by cultural values } \\
\text { and religious principles }\end{array}$ \\
\hline Objectives & Ameliorative & Transformational & Developmental \\
\hline Strategy & Opportunity Driven & Theory of Change Driven & Local Needs and Result Driven \\
\hline Project selection & Responsive & Proactive & Supportive \\
\hline Investment decision & Subjective & Objective & Mandatory; Discretionary \\
\hline Project management & Limited Engagement & Extensive Engagement & Holistic Engagement \\
\hline Partnerships & Low Commitment & High Commitment & Value-based commitment \\
\hline Project evaluation & Qualitative & Quantitative & Longitudinal and Trail-and-Error \\
\hline Keywords & $\begin{array}{l}\text { Community cohesion; beneficence; charity } \\
\text { initiatives }\end{array}$ & $\begin{array}{l}\text { Equal access to opportunities; } \\
\text { scientific approach; result } \\
\text { driven initiatives; individual- } \\
\text { ism; }\end{array}$ & $\begin{array}{l}\text { Traditional religious and cultural values; } \\
\text { legacy; family reputation, developmen- } \\
\text { tal goals; responsible capitalism }\end{array}$ \\
\hline
\end{tabular}

Source Author's elaboration from Harvey's et al. JBE (2021 p. 34)

execution of philanthropy tends to rely on informal metrics. Schools and universities might be supported because past generations of the family also supported them, and there is little energy to change course or even a hubristic belief that long-established strategies do not need to be re-evaluated.

We argue, then, that the existing literature does not comfortably capture the phenomenon of philanthropic foundations in emerging markets and their drivers for philanthropic behavior. We conjecture that spirituality is likely to be a strong driver for this philanthropy.

\section{Methodology and Dataset}

We analyze the ethics of philanthropy in emerging markets foundations through a historical approach based on oral history sources triangulated with external public information. The study is based on 70 oral history interviews from 18 countries featuring business leaders linked to foundations. Giacomin and Jones (2021) provides a full list of interviews used. This subset is drawn from an on-going database comprising 144 interviews in 26 countries (as to July 2020).

\section{Historical Methodology and Oral History}

Our methodology follows the established norms of historical research in management, organization, and entrepreneurship (Bucheli \& Wadhwani, 2014; MacLean et al., 2016; Wadhwani et al., 2020). In researching SP, we implemented an abductive approach, typical of historical methodology
(Dubois \& Gadde, 2002). This involves an iteration between theory and sources (in this case oral history interviews), so that the concept is rooted in existing literature but refined through the analysis of empirical data.

We engage in a historical comparative analysis of business leaders' recollections and memories in the form of oral histories to analyze their ethics behind their foundations' activity in different countries. Oral history refers to the collection, transcription, and recording of memories and voices directly from participants of past events (in video or tape interviews) and their preservation and interpretation as historical sources (Ritchie, 2010). It is acknowledged as a preferred longitudinal research methodology in emerging economies because alternative data sources, such as wellorganized national and corporate archives, are often absent or inaccessible (Austin et al., 2017; Jones \& Comunale, 2019).

The fact that oral histories rely on specific people's testimonies to understand the past also explains why the "ethical standards for oral historians [...] require using real names and identities of those they interview" (Quilan, 2010, p. 26). As a result, this type of interview is seldom anonymous. As for structure, oral histories resemble semi-structured interviews as they allow for interviewee's digressions within preset questions, which are framed using external sources or even contain elements of triangulation (Yates, 2014, p. 277).

Finally, we apply the "history method triad" (Bucheli \& Wadhwani, 2014) including: (i) source criticism, i.e., acknowledging the potential intrinsic biases in the source material; (ii) hermeneutic approach, i.e., contextualize the 
actions and motives of individuals emerging in the empirical material as "temporally" embedded and constrained; (iii) triangulation, i.e., cross-checking data for convergent or divergent interpretations.

\section{The Creating Emerging Markets Project at Harvard Business School}

To the authors' knowledge, the CEM database represents the largest oral history archive of high-profile business leaders in emerging markets. The interviews were undertaken between 2008 and 2020. The transcripts are publicly available online through the CEM database held at the Harvard Business School, which allows for result replication.

Each oral history in the project consists of a lengthy semistructured life-history interview conducted by Harvard-affiliated faculty. The interviewees were chosen after extensive consultation with Harvard faculty and regional research centers with strong local expertise and networks. A balance was sought of region, industry, and gender.

As a critical selection criterion, interviewees were required to possess three decades of senior leadership and to be perceived as highly impactful figures in their country. The emphasis on interviewing people with three decades of experience permitted a longitudinal perspective, which is invaluable as many foundations are multi-generational (Austin et al., 2017).

The resulting interviews present a homogeneous but loose format that aims at retracing the leaders' careers and at capturing long-term recollections of their business environment, and the most salient times of their business journey (Gao et al., 2017). Interviewers did loosely follow a set of prepared questions and often triangulated by citing and or incorporating external elements in the questions, like printed sources or pictures and had interviewees comment on them.

A further difference between CEM and studies that keep participants anonymous was that the interviewees had to commit in advance to provide an extensive and open interview. They were required to sign a document granting copyright to Harvard University, allowing publication (Gao et al., 2017). They were permitted to review the transcript for factual inaccuracy, but any other change from the transcript was discouraged. The public nature of these sources likely resulted in self-selection of individuals holding beliefs about the positive social role of business. In addition, a screening process ruled out people known to be highly corrupt, if not criminally indicted. Still, three of the Latin American interviewees either faced criminal investigations after their interviews or were revealed posthumously to have behaved unethically (i.e., Claro, Quesada, Salinas-Pliego).

Finally, we triangulated each oral history to fill potential gaps and ensure the internal validity and reliability of these reconstructions. Thus, we built our database by combining and integrating the information provided by the interviewees with external data on them. Besides being a standard methodology for these sources, this practice is consistent with other studies of non-profit organizations (Bhatnagar et al., 2020; Harvey et al., 2020), as it allows to work with more homogeneous "profiles" of each interviewee's philanthropic activity. We accessed different forms of qualitative data and public sources, such as corporate and foundation websites, newspapers, academic publications, press releases, and other interviews or statements. Table 2 includes an exemplar of interviewee philanthropic profiles.

\section{Biases in Foundation Dataset}

This article employs the 70 CEM interviews where the interviewees were involved in a foundation as defined here. Table 3 provides details on the foundation dataset and interviewees' categorization.

The dataset has several idiosyncratic biases. First, there are biases in the geographical distribution of the interviews across regions. South and Southeast Asia and Latin America account for the lion's share of the foundation data points with 27 and 29 interviewees, respectively. Within each region, some countries are well represented, and others are entirely absent. India accounts for most South \& Southeast Asian interviews and for 19 of the 27 foundations. Turkey accounts for five out of seven foundations of the Middle East group. The African group only has foundations established by leaders based in, or originating from, Kenya, South Africa, and Sudan.

A second bias concerns gender. This mirrors the underrepresentation of women in business worldwide, but especially in some of the selected countries, where gender stereotyping has been persistent. Female business leaders are only involved in 10 out of the 70 foundations. Seven of these women were sole founders of their foundation (i.e., Aga, Aziz, Mazumdar, Dudeja, Kidwai, Maziya, and Fortabat), and half of them were based in South Asia. In Latin America, only three women were involved in the 29 foundations in the sample, and only one was the main initiator of the organization.

Third, two-thirds of the interviewees, 55 out of 70 (78.5 percent), are family members, except in Africa, where executives are more prominent and represent four of the seven interviewees (Austin et al., 2017, p. 545).

Finally, in the Turkish interview set all the interviewees represent the Turkish business sector identified with the secular industry association TUSAID (founded in 1923), while none of the interviewees were affiliated with the alternative and Islamist association MUSIAD, the fastest-growing group since its establishment in 1990. 
Table 2 Interviewee profile exemplar

\begin{tabular}{|c|c|}
\hline Profile categories & Public information \\
\hline Name & Tahir, Dato' Sri Prof. Dr \\
\hline Country & Indonesia \\
\hline Company & Mayapada group (Diversified) \\
\hline Gender & Male \\
\hline Role & Family business \\
\hline Foundation & Tahir foundation (1986) \\
\hline Mission statement & $\begin{array}{l}\text { As an expression of the Founder and his family's gratitude and Christian faith, Tahir Foundation aims to } \\
\text { improve the lives of Indonesians by providing access to adequate healthcare and education, especially for } \\
\text { those facing the greatest barriers to the advancement of their quality of life }\end{array}$ \\
\hline Programs & $\begin{array}{l}\text { Jr. NBA Tahir Foundation Scholarship; Free Cancer Treatment For Children Program; Free Heart Surgery } \\
\text { Program }\end{array}$ \\
\hline Other info & Partnership with Bill and Melinda Gates Foundation on HIV research; Donations for Refugee Camps in Syria \\
\hline Sources & $\begin{array}{l}\text { https://tahirfoundation.or.id/en; "Bill Gates Foundation Comes to Indonesia to Join Fight against Diseases". } \\
\text { Indonesia-Investments.com. Indonesia Investments. } 10 \text { January 2014. Retrieved } 20 \text { January } 2014\end{array}$ \\
\hline Quote from interview & $\begin{array}{l}\text { So when I set out to make a contribution to society, I ask myself, what is the best point of entry? How do I } \\
\text { want to act? Do I use the old style and link with a few elite people, few powerful people, few power govern- } \\
\text { ment officials? I don't. I choose two points of entry. One is healthcare. One is education. I like to show my } \\
\text { sympathy to this nation, that I want to be a proper businessman. So I decided to contribute to education. I } \\
\text { also contributed to healthcare. That's why people now call me a philanthropist, a title I do not deserve. This } \\
\text { vision that I have can make us survive another } 100 \text { years. But if we go back to the old style, for example } \\
\text { people still showing you how influential they are, how powerful they are, saying I have this many people } \\
\text { backing me up... This will not work. It will never work again. The time is past. (...) The fourth [pillar] } \\
\text { one is philanthropy. I think in my book I mention that. Indonesia is not a rich country. Poverty is surround- } \\
\text { ing... us; when from my home I go to the office, I pass through a street. Along the street, there are so many } \\
\text { poor people. As an Indonesian Chinese, who are born in this country, our Chinese have an old saying that } \\
\text { you are born, you grow, and you die in one place. So, a lot of reporters ask me the same question. Why do } \\
\text { you have to do philanthropy for Indonesia? There's no free lunch, Tahir. How you explain that? I say, "I } \\
\text { perfectly } 100 \text { percent support there's no free lunch. Where you are wrong is the sequence. The sequence } \\
\text { is I have already eaten the lunch. I enjoy all the facilities from this country. No Indonesia, no Tahir. Not } \\
\text { China-even though I'm Chinese. Not Singapore-even though I love Singapore. But this land, Indonesia, } \\
\text { made Tahir like this. So, the logical consequence is that I will give back. That's one reason. Second reason, } \\
\text { my religion. I'm Christian. The Bible clearly stated that Almighty God never gave a right to own anything } \\
\text { in this world. ... Only give a right to manage, to steward, not to own. (..) So, I try to take another way } \\
\text { around. Why don't I use my position to get more money for me? That's when you mess up. To be the hero } \\
\text { will never be an objective of life. This is a means. This is a channel to reach the genuine meaning of your } \\
\text { life. Be a blessing. That's why I serve the refugees }\end{array}$ \\
\hline Keywords & Healthcare; Education; Nationalism; Poverty; Religion; Long-term approach \\
\hline Themes at unique mention & 1a. Responsible Capitalism; 1b. Values; 2a. Institutional Voids; 3a. Type of Investment \\
\hline SP? & YES \\
\hline $\begin{array}{l}\text { Total score (average of scores for } \\
\text { second-order theme mentioned) }\end{array}$ & $(3+3+2+1) / 4=2.25$ \\
\hline
\end{tabular}

Source Authors' compilation

\section{Data Analysis: Measuring Spiritual Philanthropy}

After identifying the 70 interviewees involved in foundations, we created a full philanthropic profile for each as a basis of triangulation (Table 2). We combined interviewees' quotes on philanthropy and foundation activity with external public information on the same topic. For each interview, we isolated the statements about their philanthropy and the work of their foundation. We obtained a total of 218 text segments comprising over 14,000 words.
These statements were used to investigate the ethics of SP through a grounded theory method (Strauss \& Corbin, 1994). The quotes were interpreted as a record of each interviewee's perceptions and motives of their activity (Maclean \& Harvey, 2020). In investigating the concept of SP, we focused on the declared motivations, drivers, strategies, and initiatives of their foundations and analyzed how the interviewees explained and made sense of them (Harvey et al., 2021). 
Table 3 Foundation dataset summary

\begin{tabular}{lllclc}
\hline Data & Total & Africa & Latin America & Middle East & $\begin{array}{c}\text { South and } \\
\text { Southeast } \\
\text { Asia }\end{array}$ \\
\hline $\begin{array}{l}\text { Interviewees } \\
\text { Countries }\end{array}$ & 70 & 7 & 29 & 7 & 27 \\
Gender & 18 & 3 & 6 & 3 & 6 \\
$\quad$ Female & 10 & 1 & 3 & 1 & 5 \\
$\quad$ Male & 60 & 6 & 26 & 6 & 22 \\
Position & & & & 6 & 21 \\
$\quad$ Family member & 55 & 3 & 25 & 1 & 6 \\
Executive & 15 & 4 & 4 & & \\
\hline
\end{tabular}

Source Authors' calculations from CEM database, July 2020
We performed multiple readings of the text segments to develop a data structure (Creswell, 2013; Strauss \& Corbin, 1994). As a first step, we engaged in manual-open coding using a list of over 80 keywords and obtained about 46 firstorder terms (Table 4). Second, we analyzed the data again and engaged in axial coding to determine seven second-order themes (Salvato \& Corbetta, 2013). These summarize the main drivers and features of SP. Table 4 includes the firstorder keywords, the list of the second-order themes, the definition, and the number of unique mentions for each theme across all interviews. Then, we aggregated these categories into three main dimensions following the Gioia method for theoretical refinement (Gioia et al., 2013). These are: (i) the values, philosophy, and principles behind the foundations' activity (vision); (ii) the strategies implemented by foundations and the goals behind their commitment (strategy); and (iii) the content of philanthropic initiatives and how they were executed (execution). Figure 1 provides a summary of the steps.

After analyzing the complete profiles of the interviewees, we identified 55 out of 70 leaders whose profiles aligned with our definition of SP. The excluded profiles lacked textual evidence in either the CEM interviews or other external information consulted or simply did not correspond to the $\mathrm{SP}$ definition. We used the $55 \mathrm{SP}$ profiles to determine how explicitly business leaders articulated their spiritual ethics of philanthropy. This required a further round of analysis of the text segments in triangulation with the external information that formed each interviewee's full profile. Then, we reckoned that for some leaders, we relied more on external information than for others, namely, some themes were weaker than others in identifying SP, if considered in isolation and without the support of triangulation.

Therefore, we ranked the explicatory power of themes according to the macro-dimension in our text analysis and associated them with varying "strength" of SP in the quotes (Reilly et al., 2020, p. 587). We assigned subjective scores on a three-point ordinal scale (strong-mild-weak) to each dimension to reflect their ability to describe SP without the integration of external information (Harvey et al., 2021), which we define as "degree of explicitness" (Bryman, 2008; Miller \& Salkind, 2002). Categories within the "vision" dimension received 3 points; within "strategy" 2 points; and within "execution" 1 point (Table 4). This because the "vision" dimension includes themes that are more explicitly associated with stronger levels of SP, according to our definition, such as values, responsible capitalism, and family legacy. When it came to "strategy," we noticed it was necessary to integrate external information. For instance, in the case of Latin America, several interviewees focused heavily on execution, and we could only categorize profiles as SP through triangulation with external information.

Finally, each interviewee received a total score. For each interview, each different second-order theme was assigned the score of the corresponding dimension, if it was ever mentioned (e.g., if the "values" theme appeared it would be assigned as score of 3 as per "vision" dimension, regardless of how often it appeared). The final score would result from the sum of scores for each second-order theme mentioned, divided by the total number of distinct second-order themes appearing in the whole interview. Thus, the minimum score would be 1 , and the maximum would be 3 , if only all the "vision" themes were mentioned. This is the rate of high-value second-order themes mentioned. Intuitively, it can be interpreted as the "strength" of SP and used to draw conclusions on how SP is perceived across different geographies and cultures. Table 5 shows the measurement of SP degree of explicitness by region, Fig. 2 maps our process, and Table 2 provides an example of the score computation. 


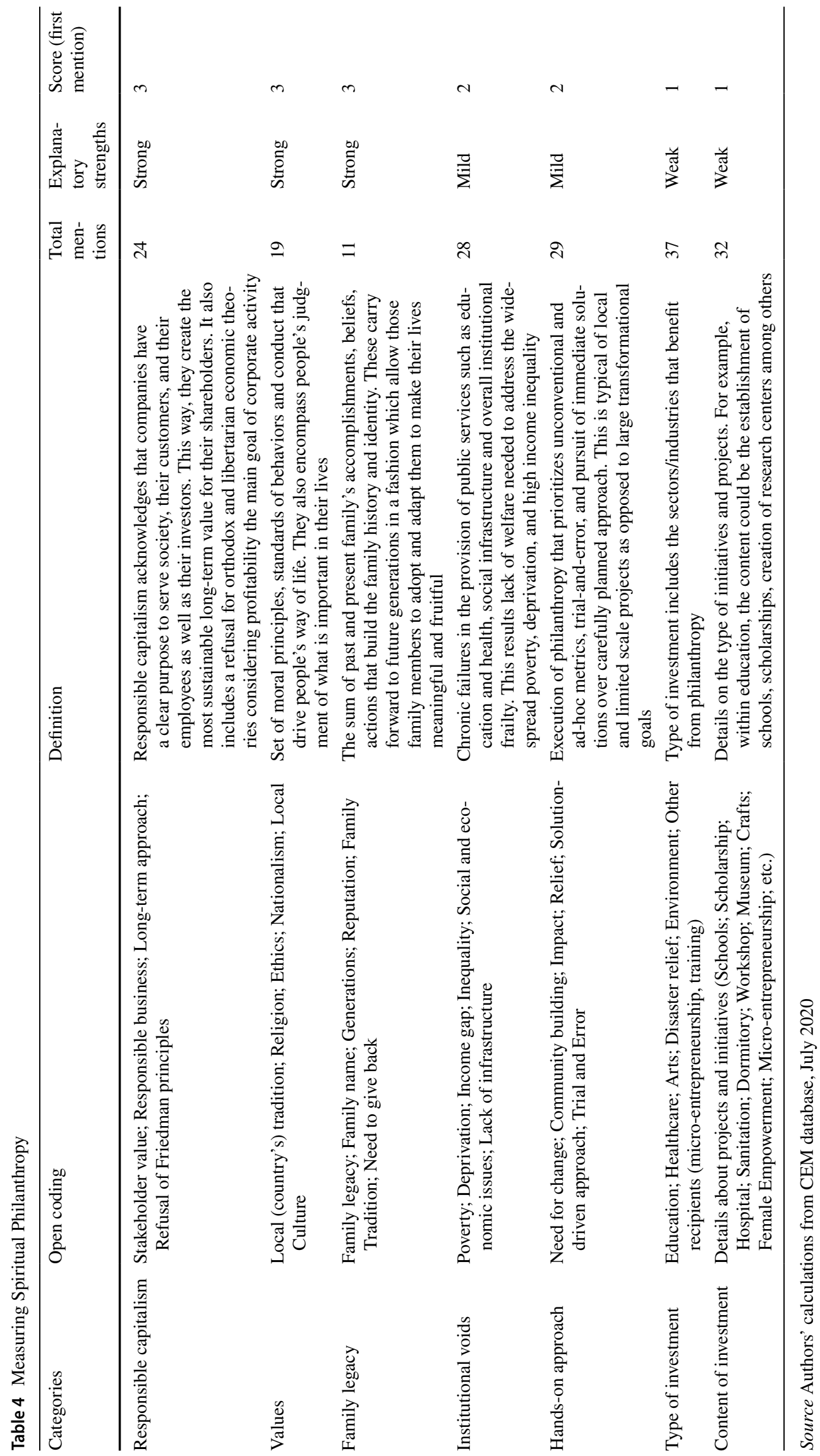




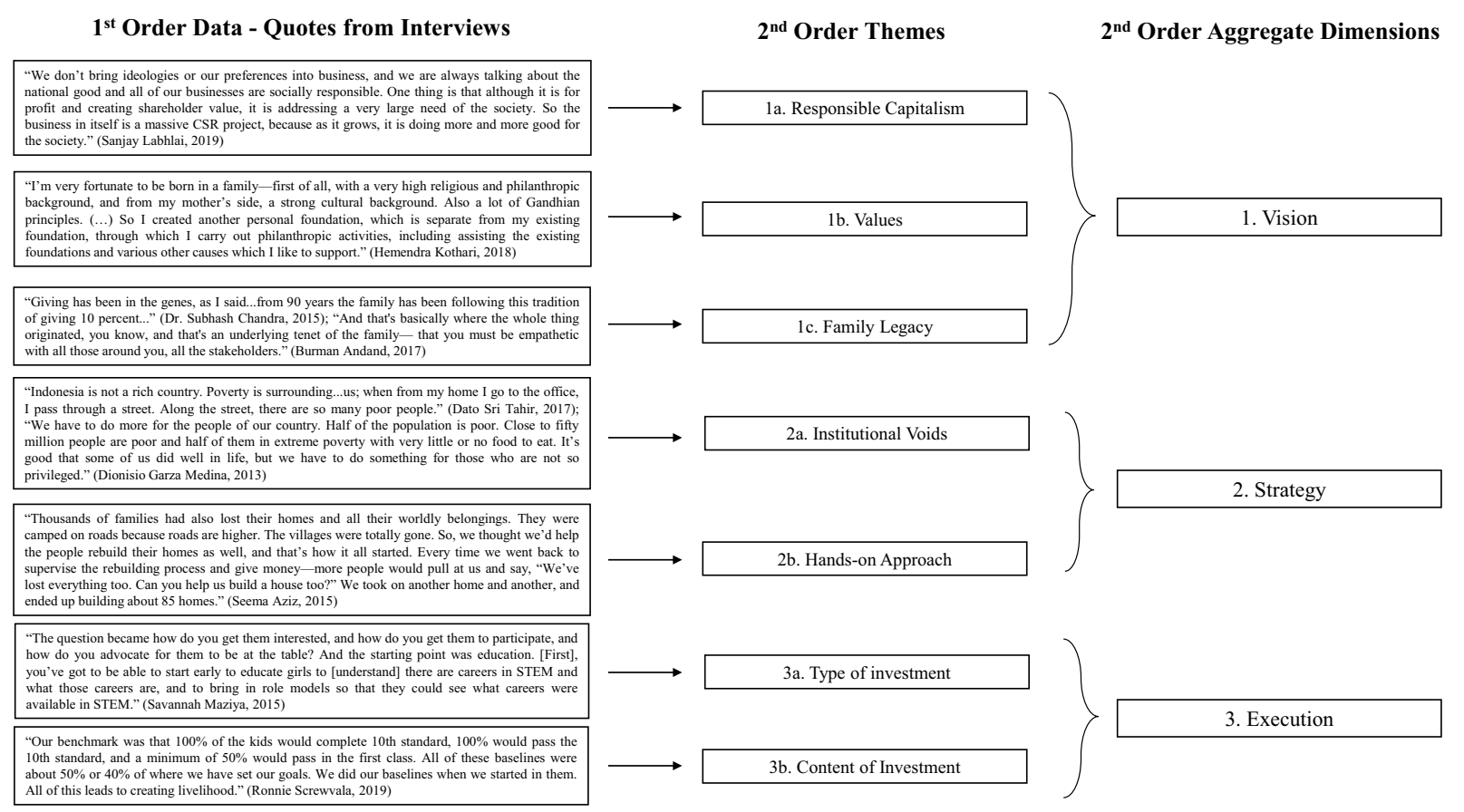

Fig. 1 Text analysis: Data structure

Table 5 Strength of Spiritual Philanthropy across foundations

\begin{tabular}{llllll}
\hline SP & Total & Africa & Latin America & Middle East & $\begin{array}{l}\text { South and } \\
\text { Southeast } \\
\text { Asia }\end{array}$ \\
\hline Number of foundations & 70 & 7 & 29 & 7 & 27 \\
Number of SP interviews & 55 & 6 & 23 & 5 & 21 \\
Average score & 1.90 & 1.88 & 1.66 & 1.83 & 2.18 \\
$\begin{array}{l}\text { Average score weighted by } \\
\text { theme mentioned }\end{array}$ & 3.27 & 4.17 & 2.74 & 4.40 & 3.33 \\
\hline
\end{tabular}

Source Authors' calculations from CEM database, July 2020

\section{Findings: Foundations in Emerging Markets \\ Notes on Foundation Type}

Foundations in our sample surfaced as tightly linked to family-managed business groups. As shown in Table 3, 55 business leaders, out of 70 involved in a foundation, were family members in their firm, and only 15 were executives. Then, foundations were grouped into two ideal types based on their purpose and style, either as PPF or IF, following the discussion in Sect. Foundations and Ethics of Philanthropy. Table 6 shows that 46 out of the total 70 foundations were categorized as IFs, generally listed as charitable trusts and operating as philanthropic arms of family business groups. Some family business groups (i.e., Tata, Godrej, Koç, Sabancī) used the family foundation or trust as an umbrella institution for several of their operations, and not only philanthropy. This allowed companies to maintain control over their assets and ensured continuity of family values, name, and legacy across generations (Mayer, 2019, pp. 40-41).

The discrepancy between "family members" (55) and IFs (46) is explained by the fact that 9 business leaders did not connect their foundation to their family business groups but created NGOs or other types of foundations clearly disenfranchised from their core-business activity. These were generally created on the side of the interviewee's family business or after they had retired. These, together with other institutions not directly linked to a for-profit activity (i.e., founded by an executive), are part of the remaining 24 foundations categorized as "PPFs" (see Table 6).

Several PPFs were associated with SP and exercised a developmental role in their reference context, despite some critical voices (Jakwa, 2018). This was the case of Mo Ibrahim Foundation in Africa and Seema Aziz's CARE Foundation in 


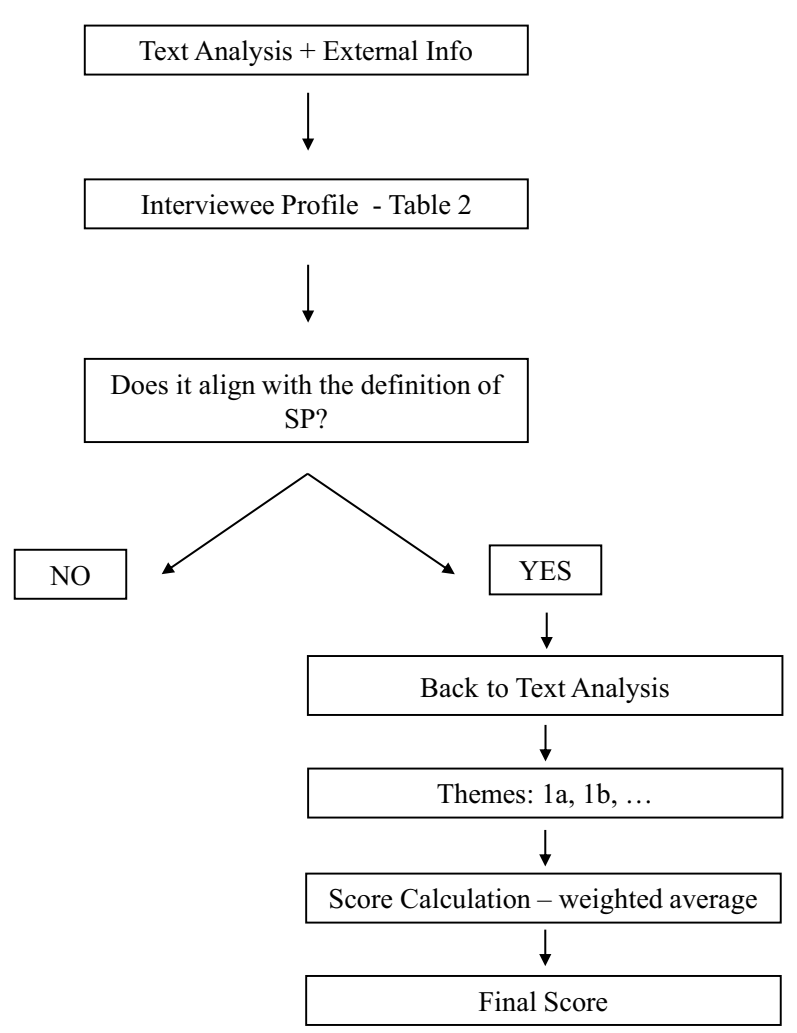

Fig. 2 Process map to assign "explicitness" scores

Table 6 Foundation type

\begin{tabular}{llllll}
\hline Type & Total & Africa & $\begin{array}{l}\text { Latin } \\
\text { America }\end{array}$ & Middle East & $\begin{array}{l}\text { South and } \\
\text { Southeast } \\
\text { Asia }\end{array}$ \\
\hline $\begin{array}{c}\text { Industrial } \\
\text { founda- } \\
\text { tions }\end{array}$ & 46 & 3 & 20 & 5 & 18 \\
$\begin{array}{c}\text { Pure phil- } \\
\text { anthropic } \\
\text { founda- } \\
\text { tions }\end{array}$ & 24 & 4 & 9 & 2 & 9 \\
\hline
\end{tabular}

Source Authors' calculations from CEM database, July 2020

Pakistan, among others. This category also included corporate foundations linked to specific companies rather than to families and individual entrepreneurs, primarily delivering CSR for their respective corporations such as WPP Foundation in India and Fundación Térpel in Colombia.

\section{Spiritual Philanthropy in Emerging Markets Foundations}

The concept of SP emerged from 55 out of 70 profiles of interviewees. Table 7 records the number of mentions for each theme across different regions.

\section{Vision of Spiritual Philanthropy in Foundations}

We propose that the "vision" dimension is strongly associated with the SP concept. It is a combination of philosophical approaches to philanthropy and values, beliefs and cultural drivers that motivate it. The discourse analysis identified three main themes. First, 24 out of the 55 SP business leaders made a direct connection between their giving and a responsible approach to capitalism (Table 7). This differs from standard CSR policies, often akin to marketing, and encompasses a philosophy of business that prioritizes social impact over sole profitability. In this view, foundations helped companies reach social goals and contribute to the welfare of stakeholders like customers, employees, and civil society. As Rahul Bajaj, head of the diversified family business group Bajaj in India, noticed:

[As a business leader] you have to take care of the society in which you operate, which enables you to earn that money. You have to repay the society, not at the cost of your company. It's not this or that. It has to be all that and this. In fact, the stronger you are, the better philanthropic activities you can do.

This provided several synergies by transferring business skills to solving societal challenges. James Mwangi, Kenyan financier and founder of Equity (Bank's) Foundation, one of the largest in Africa, observed:

Fortunately, now, we use the infrastructure of the corporate to scale that thinking [of positively impacting society]. (...) It didn't matter how philanthropic I would have loved to be. I've realized you can never match corporates that can lay out the capabilities at their disposal for the benefit of the society. (...) The 9000 staff of Equity Bank are the agents of the Foundation. (...) The human capital, in terms of leadership, provides technical expertise to the Foundation.

For the most part, members of family businesses discussed this theme in South and Southeast Asia (12 out of 24) and in the Middle East, although some cases were evident also in Africa and Latin America.

Specifically, four business leaders (Cavalier and Cortés in Colombia; Mahindra and Godrej in India) explicitly distanced themselves from Milton Friedman's (1970) shareholder-value doctrine. José Cortés, president of the Colombian-based diversified family business Grupo Bolívar, stated:

Friedman, for example, says that companies' social efforts must not be made directly but through their shareholders, with their dividends and returns. I don't think that way. I believe that companies play a 
Table 7 Mentions of Spiritual Philanthropy themes across geographies

\begin{tabular}{lllllll}
\hline Dimension & Themes & Total & Africa & Latin America & Middle East & $\begin{array}{l}\text { South and } \\
\text { Southeast } \\
\text { Asia }\end{array}$ \\
\hline \# SP interviews & & & & & & 21 \\
Vision & Responsible capitalism & 24 & 2 & 6 & 5 & 12 \\
& Values & 19 & 2 & 5 & 1 & 11 \\
\multirow{3}{*}{ Strategy } & Family legacy & 11 & 1 & 2 & 2 & 6 \\
& Institutional voids & 28 & 5 & 5 & 4 & 14 \\
Execution & Hands-on Approach & 29 & 5 & 10 & 3 & 11 \\
& Type of Investment & 37 & 4 & 21 & 5 & 7 \\
& Content of Investment & 32 & 5 & 14 & 4 & 9 \\
\hline
\end{tabular}

Source Authors' calculations from CEM database, July 2020 key role in this regard and have a number of obligations with all communities across the nation.

As a second theme, 19 out of 55 SP business leaders mentioned the value system behind their foundations' initiatives. Again, the majority (11 out of 19) were leaders of family business groups in South and Southeast Asia. They explained their engagement as resulting from their patriotism, their willingness to support local culture, and their religious beliefs. For example, Sri Lankan tea producer Fernando Merrill and Indonesian entrepreneur Dato Sri Tahir expressed a strong commitment to their Christian faith. Other active Christians included James Mwangi in Kenya and multiple Latin American leaders. Five Indian leaders, as well as Manu Chandaria, an ethnic South Asian Jain in Kenya, mentioned the strong influence of Gandhian principles in their philanthropy.

Finally, foundations were employed by 11 business leaders to express family values and philanthropic legacy. The majority, 8 out of 11, came from India and Turkey. For example, Subbash Chandra, head of the Indian diversified business group Essel, described his foundation's work as the vehicle of a century-long family tradition:

Giving has been in the genes, as I said...from 90 years the family has been following this tradition of giving 10 percent... I have seen it when I was 8-10 years old, I used to sometimes total up the books sitting and while learning with [my] grandfather in the shop and they had a ledger account of philanthropy.

Overall, the Asian countries accounted for most of the mentions for the "vision" themes ( 29 out of 54 in Table 7). Philanthropic work was described as a natural consequence of leaders' family traditions, life philosophy, and value systems, intended as an evolving and ever-improving approach to business and life.

\section{Strategies of Spiritual Philanthropy in Foundations}

Foundations in emerging markets displayed specific features also in terms of their donors' commitment and purpose. The SP concept is only partially explicit when leaders discuss the "strategy" dimension, which therefore is associated with "mild" levels of SP. Thus, in explaining their goals, business leaders referred to their developmental objectives (as per SP definition), but their words did not always directly involve spirituality. They instead connected their spiritual background with empathy toward local conditions.

The discourse analysis identified two themes matching our definition: the willingness to bridge institutional voids and a hands-on, solution-driven approach in their foundation work. Most SP interviewees, 28 out of 55, linked their social engagement with the widespread presence of dire poverty where they operated. In these contexts, even when being wealthy for generations, these leaders were repetitively exposed to severe deprivation in their daily lives. This was evident in Africa and India, as Ratan Tata, head of Tata Trusts, one of the oldest and largest diversified business groups in India, pointed out:

I think in a country like India, or in the developing world, (...) you can't just have ivory towers with depressed conditions all around them and feel satisfied. One has to say that you need to upgrade the lower elements to a level of prosperity. (...) You have to look at what it takes to lessen the discrepancy between the haves and the have-nots. (...) By bringing everybody up. There may be some sacrifice for the very wealthy, but not to bring them down. To bring the others up to a level where there's sustainability there.

In environments where public resources are scant, and government institutions are frail, interviewees thus used their foundations to supplement or complement the government to provide services such as education, health, sanitation, and infrastructure upgrading. Indeed 29 among the $55 \mathrm{SP}$ 
interviewees described their foundation approach as problem-oriented, tailored to the local environment, and close to the immediate needs of the local communities.

This interpretation of the foundation's role prioritizes localized impact based on practical and hands-on solutions rather than globally-oriented transformational goals. Robert Brozin, founder of the South African restaurant chain Nando and of Goodbye Malaria in Mozambique, illustrated this point:

I was approached a few weeks ago by the Global Fund and the Bill \& Melinda Gates Foundation to help them [fighting malaria] in maybe one or two other countries in Africa. My view is that we can't really extend beyond Mozambique, because we want to eliminate malaria in Mozambique by 2030. We've got to be focused. We've got to be completely head-down. And we're not going to be the experts.

A local focus does not mean that such foundations are smallscale or lack ambition. For instance, the Pakistani fashion entrepreneur Seema Aziz exercised a major positive impact on the primary school system in Lahore through her CARE Foundation, counting almost 900 schools and 300,000 enrolled students in 2020.

It seems, however, that many foundations devoted limited time or resources to full-scale impact assessment. For example, several foundations that supported schools confined their impact metrics to simple counting of enrolled pupils. There was little attention to educational content or experiments with alternative pedagogies. Path dependency was also observed, as schools and other facilities were funded because they had "always" been funded, rather than due to any systematic measurement of impact.

Overall, almost all the SP interviewees in Africa and the Middle East, and a large majority of Asia and Latin American ones, mentioned at least one of the "strategy" themes. The analysis showed that foundations in emerging markets have primarily been employed to confront pressing social issues in local communities. They filled voids where governments were unable or unwilling to provide adequate resources.

Table 8 Foundation activity

\section{Execution of Spiritual Philanthropy}

The last dimension, "execution," recorded interviewees' discussions on the types of investment and the content of projects. These align with SP when they support bottomup initiatives, are incremental in scale, and address urgent needs. Because of its descriptive nature, this dimension was less directly associated with SP and required more triangulation with external information.

Most of the interviewees referred to this dimension. As for themes, the type of investment was mentioned by 37 out of 55 SP business leaders. They comprised most of the African, Middle Eastern, and Latin American interviewees, but only 7 out of a total of 21 in South and Southeast Asia. As shown in Table 8, there was a homogeneous distribution in terms of foundation investment. All foundations in the SP subset operated in education, although in different sectors. About half of them engaged in "other projects," which generally involved community support, sports, training, and skill development, while healthcare, arts, and environment followed. This is in line with foundation activity in the West (Anheier \& Toepler, 1999), although initiatives, execution, and impact might significantly differ (Giacomin et al., 2019).

Finally, 32 business leaders, almost half of them in Latin America (14), explained in detail the content of their projects and initiatives. Investment in education featured the construction of schools and provision of scholarships, and different forms of training. In India, Pakistan, and Africa this focused on primary education, while universities were founded in Turkey and Latin America. Health initiatives encompassed construction of hospitals, training of personnel, and some specific program such as children malnutrition, malaria relief, etc. Cultural initiatives included the creation of museums and exhibitions. In Colombia, and to a lesser extent Peru, foundations were modeled following the example of large US foundations. They were paternalistic as initiatives were implemented following a top-down approach, but they displayed a practical attitude toward their projects, prioritizing specific goals such as female education and assistance to the poor

\begin{tabular}{lllclc}
\hline Type & Total & Africa & Latin America & Middle East & $\begin{array}{l}\text { South and } \\
\text { Southeast } \\
\text { Asia }\end{array}$ \\
\hline Education & 55 & 5 & 25 & 5 & 20 \\
Healthcare & 25 & 3 & 5 & 3 & 14 \\
Environment & 16 & 2 & 7 & 0 & 7 \\
Arts and culture & 15 & 1 & 4 & 4 & 6 \\
Other & 26 & 3 & 7 & 4 & 11 \\
\hline
\end{tabular}

Source Authors' calculations from CEM database, July 2020 
in rural communities rather than strict planning and result measurement (Rojas \& Morales, 2005, p. 166).

\section{Discussion}

\section{Theoretical Implications}

Corporate philanthropy takes many forms in emerging markets. Firms do CSR themselves-and in some countries, like in India since 2014, larger businesses are mandated to do so (Bhatnagar et al., 2020; Sundar, 2017). They also establish foundations, some of whom perform the primary CSR activity, while others have a wider remit. The evidence collected suggests that the oldest foundations in emerging markets resemble the model of IFs found in Europe, while the PPF type exists but was established more recently on the wave of successful US foundations by tech-billionaires.

Liket and Simaens (2015)'s taxonomy of corporate philanthropy research stressed that studies focusing on motives of philanthropy at the individual and organizational levels tended to be normative in their conclusions; presented highly contextual motives; and failed to clarify the importance of understanding these motivations. In this article, we have sought to respond to such criticism by showing that many of the foundations operating in emerging markets have been used as vehicles of SP. Albeit partially context-dependent, the evidence from 18 emerging countries helped us provide a more granular and multifaceted view of the ethics of philanthropy in these under-researched settings. Because of the high levels of income inequality, widespread conditions of dire poverty, and the chronic shortage of essential services, foundations played an important developmental role in these countries.

The conceptualization of SP also provides a counterfactual to previous research arguing that foundations in these contexts are often resulting from the adaptation and modification of a developed countries model to fit local conditions (Jamali, 2010; Jansons, 2015). In fact, the categorization based on "customary" and "entrepreneurial" philanthropic ethics elaborated by Harvey et al. (2021) for Britain seems ill-fitted to explain the ethics of many business leaders operating foundations in the emerging world. For this reason, SP differs markedly from the ethics of CP and EP, especially in terms of "vision" and "strategy." As for vision, while for EP and CP initiatives are implemented respectively to fulfill the expectations of society and as an investment toward transformational social change, SP represented a value-driven and long-term approach directed to multiple stakeholders. As for strategies, SP's interpretation of the foundation's role was like EP as it conceived it as a vehicle to tackle major challenges. However, EP promoted universal objectives to be solved through long-term projects, while SP leaders prioritized local initiatives within their home countries. This type of philanthropy was based on practical and hands-on solutions, although it sometimes led to suboptimal use of resources.

Our study showed that family-owned business groups were more likely to display a SP approach through their foundation (41 out of 55 SP leaders). This is in line with prior research showing family businesses' tendency toward ethical behavior in at least some contexts (Astrachan et al., 2020), but it is also explained by the need to safeguard reputations to enhance survival prospects in frequently volatile conditions (Gao et al., 2017). This was particularly noticeable in family business groups (primarily in South Asia and Turkey), which featured IFs as high-profile institutions representing the company's traditional involvement in the community. These foundations embodied values connected to the family's or entrepreneur's local history and image. As a result, foundation activity was tightly intertwined with the family's reputation and status.

Like IFs in the developed world, their equivalents in emerging countries were used both to undertake charitable activities but also to ensure continuity and control across the groups' diverse operations, which often included outside shareholders (Mayer, 2019, p. 162). Despite the largely debated pitfalls in family business succession, some studies argue that families prefer long-term orientation in their decisions (Lumpkin \& Brigham, 2011). This can result in more ethical behavior (Long \& Mathews, 2011) but also lead companies to introduce governance mechanisms and organizational precautions to maintain strategic control of family assets while their business expands (Chrisman et al., 2018).

\section{National Variations and Practical Implications}

While SP was observed across all geographies in our sample, we found significant variation in the degree of explicitness in which business leaders articulated their philanthropic ethics and spirituality both across and within macro-regions (see Table 4, 5 and 7).

Table 7 shows that interviewees from Africa and the Middle East mentioned more than four SP themes on average, while leaders from Asia and Latin America averaged around three SP themes each. Table 5 shows that Asian, especially Indian, business leaders spoke more openly about religion, family values, and their ethical principles (2.18 out of 3) than African ones (1.88 out of 3). The Middle Eastern interviewees also obtained high average scores, but they mentioned values primarily in the case of Turkey, where business leaders internalized religious principles, but were not associated with Islamist organizations. In the Gulf, in contrast, most interviewees concentrated on local institutional voids and the strategies deployed to tackle them. 
As for Latin America, the lower average score (1.66) and mentions of vision themes (13 out of 54) suggest that, despite qualifying as spiritual philanthropists based on external information, interviewees appeared much less open to explain their spiritual connection to philanthropy. When asked about their foundations and philanthropy, they provided details about their activities and remained silent about their motivations and goals, including religious convictions. We call this implicit SP.

This level of implicitness of SP in Latin America probably reflected the peculiarities of religion and class in the region. Research on Chile found that business élites in Catholic milieus distance themselves selectively from what the Church mandates but maintain a strong link with their religious identity and their belief in the supernatural (Thumala-Olave, 2007). They also tend to conflate their religious affiliation with their social status. Philanthropy through a foundation is considered as something they ought to do as members of a certain social class or as a customary family activity. Although almost all Chilean interviewees in the sample were involved in a foundation, they did not discuss religion. Yet external sources identify several, including Andronico Luksic Craig, Roberto Angelini-Rossi, Ricardo Claro, and Reinaldo Solari, as very active in powerful Catholic associations. These included Opus Dei, a secretive clerical organization affiliated to the Catholic Church, whose members do not disclose their affiliation (Allen, 2007). Thus, in Chile, a discrete attitude about public discussion of religion probably reinforced pressure for isomorphic behavior among the small and homogeneous business élite.

A further explanation for the implicitness of Latin American interviewees might have been the high levels of insecurity found in many countries. Argentina, Chile, Colombia, Mexico, and Peru have all experienced prolonged bouts of terrorism and kidnapping of affluent people for ransom. This is likely to discourage people from seeking high public profiles. The periods of left-wing and anti-business governments in many countries may also encourage discretion. There might be a fear of public retaliation from being accused of whitewashing, using their foundation for sketchy purposes, such as tax evasion, or provoking government intervention in their operations (Turitz \& Winder, 2005). It is noteworthy that some of them were unwilling to quantify the scale of their foundation activity. While large foundations in South Asia often provide detailed data on their operations, the work of many foundations in Latin America is discrete, and often even basic statistics are not public.

Practitioners now have an additional tool to evaluate national variations and the type of foundations they might be working with. Specifically, this research should encourage policymakers, international NGOs, and others to recognize that philanthropic foundations are heterogeneous as regards their ethical basis, modes of operation, and motivation when compared to developed countries. We have suggested that the culture and practices of the founding family likely influence founders behind SP foundations. They are also likely to manifest patriotic pride in both their home country and associated business enterprise. They may exhibit more patience in their strategic approach and prefer hands-on immediate projects, while eschewing the delivery of quarterly performance metrics.

Finally, this study provides insights into entrepreneurial aims in these countries. Emergent literature on spirituality and entrepreneurship (Ganzin et al., 2020) posits that successful entrepreneurship originates in dedicated action in the face of highly uncertain conditions, which in turn may be rooted in spirituality and strong values. The same rationale can be applied to philanthropy, where spirituality can offer an additional explanation behind the work of foundations operating in difficult environments. Understanding the motivations of the leaders represents an essential beginning for potential investors and donors to assessing their longterm commitment and the sustainability of their initiatives in these contexts.

\section{Concluding Remarks}

Our analysis of a sample of 70 foundations based in 18 countries aimed to understand the growth and ethical drivers of foundations in emerging markets. This article has made several contributions. First, the analysis contributed to the scarce literature on foundation activity outside the United States and Europe. Foundations and their ethics usually are analyzed within the context of corporate philanthropy (Feliu \& Botero, 2016; Gautier \& Pache, 2015). This study breaks new ground by focusing on the foundations themselves and by discussing in-depth the ethics of the business leaders behind them.

Second, we suggested that the ethical arguments against foundations in the developed world, and more particularly the "purely philanthropic" foundations found in the United States, are not entirely transferrable to foundations in emerging markets. Most of these foundations are closer to the "industrial foundations" model common in Europe but present clear differences. Whatever their model, they avoided grandiose world-making claims. They focused on addressing immediate educational, health, and social challenges in their home countries, often with a focus on minorities or sub-groups.

Third, we conceptualized SP as a distinct form of philanthropic ethics. We distinguished this from "customary philanthropy" and "entrepreneurial philanthropy" discussed in the existing literature. We found that SP motivated 55 of the 70 interviewees engaged in philanthropy when describing and organizing their work in foundations. 
Importantly, we confirmed the distinction between SP and religious belief, which has quite often motivated philanthropic foundations, especially in the United States. In our formulation, SP has a broader significance. It certainly included both religious and philosophical values, but it also incorporates broader cultural norms and local traditions, including family legacy and reputations. As many foundations were multi-generational, timelines for achieving impact were more patient than often seen with USstyle purely philanthropic foundations.

Fourth, this analysis has important implications for potential donors and partners interested in working with foundations based in emerging markets. This article has not argued that foundations influenced by SP are superior to other forms of philanthropy. Rather it has shown such foundations to be different in terms of goals, strategies, and content of initiatives. The definition of SP can provide an additional metric to investors and donors who seek to support local organizations. Conversely, failure to understand the values of different types of foundations will undermine partnerships.

This study leaves open new avenues for research. SP should be examined across different activities, geographies, and selection criteria, and developing larger sample sizes. As CEM concentrated on leaders at later stages of their careers, the most of whom were male, more research should focus on the differences (if any) of business leaders' age and gender in conducting philanthropic work. In addition, we observed that over one-half of the leaders in the sample spent extended time during their formative years in the United States and Britain. Further research should test the impact of this exposure to Western educational and cultural norms.

Finally, more research is needed to connect this ethical approach with the economic, social, and cultural impact of foundations on emerging markets. It is evident that hundreds of thousands of children have been educated through the work of the foundations described in this article, for example, but there is scant hard evidence on the quality of that education. Nor do we know whether money spent on primary, secondary, or higher education was the most socially productive or whether funding provided for education would have been better spent in other sectors, including health. Such allocation choices present acute ethical dilemmas that require research, potentially using quantitative techniques alongside detailed qualitative approaches. By deepening our understanding of the ethics of foundations in emerging markets, we aim to facilitate and inspire this research on impact and so enhance the quality of future decision-making on where and how, large sums of money are spent.

Acknowledgements We would like to thank the Division of Research and Faculty Development at the Harvard Business School for funding the research on which this article is based.
Funding Open access funding provided by Università Commerciale Luigi Bocconi within the CRUI-CARE Agreement.

\section{Declarations}

Conflict of interest The authors declare that they have no conflict of interest.

Open Access This article is licensed under a Creative Commons Attribution 4.0 International License, which permits use, sharing, adaptation, distribution and reproduction in any medium or format, as long as you give appropriate credit to the original author(s) and the source, provide a link to the Creative Commons licence, and indicate if changes were made. The images or other third party material in this article are included in the article's Creative Commons licence, unless indicated otherwise in a credit line to the material. If material is not included in the article's Creative Commons licence and your intended use is not permitted by statutory regulation or exceeds the permitted use, you will need to obtain permission directly from the copyright holder. To view a copy of this licence, visit http://creativecommons.org/licenses/by/4.0/.

\section{References}

Abdelgawad, S. G., \& Zahra, S. A. (2020). Family firms' religious identity and strategic renewal. Journal of Business Ethics, 163(4), $775-787$.

Allen, J. L. (2007). Opus Dei: An objective look behind the myths and reality of the most controversial force in the catholic church. Penguin Random House.

Amaeshi, K., Adi, B., Ogbechie, C., \& Amao, O. (2006). Corporate social responsibility in Nigeria: Western mimicry or indigenous influences? The Journal of Corporate Citizenship, 24, 83-99.

Anheier, H. K., \& Toepler, S. (Eds.). (1999). Private funds, public purpose: Philanthropic foundations in international perspective. Kluwer Academic/Plenum.

Astrachan, J. H., Binz Astrachan, C., Campopiano, G., \& Baù, M. (2020). Values, spirituality and religion: Family business and the roots of sustainable ethical behavior. Journal of Business Ethics, 163(4), 637-645.

Austin, G., Dávila, C., \& Jones, G. (2017). The alternative business history: Business in emerging markets. Business History Review, 91(3), 537-569.

Azmat, F., \& Samaratunge, R. (2009). Responsible entrepreneurship in developing countries: Understanding the realities and complexities. Journal of Business Ethics, 90(3), 437-452.

Berman, E. H. (1983). The ideology of philanthropy: The influence of the carnegie, ford, and rockefeller foundations on American foreign policy. State University of New York Press.

Bhatnagar, N., Sharma, P., \& Ramachandran, K. (2020). Spirituality and corporate philanthropy in Indian family firms: An exploratory study. Journal of Business Ethics, 163(4), 715-728.

Blowfield, M., \& Frynas, J. G. (2005). Setting new agendas: Critical perspectives on corporate social responsibility in the developing world. International Affairs (Royal Institute of International Affairs 1944), 81(3), 499-513.

Bryman, A. (2008). Social Research Methods. Oxford University Press. Bucheli, M., \& Wadhwani, R. D. (Eds.). (2014). Organizations in time: History, theory, methods. Oxford University Press.

Campopiano, G., \& De Massis, A. (2015). Corporate social responsibility reporting: A content analysis in family and non-family firms. Journal of Business Ethics, 129(3), 511-534. 
Cantegreil, M., Chanana, D., \& Kattumuri, R. (2013). Revealing Indian philanthropy. UBS AG report. Alliance Publishing Trust.

Carnegie, A. (1889). Wealth. North American Review, 148, 653-665.

Caussat, P. (2017). Competing for public acquaintances: The case of the reliance group in India. In M. de la Rama \& C. Rowley (Eds.), The changing face of corruption in the Asia Pacific (pp. 209-219). Elsevier.

Chakrabarty, B. (2012). Corporate social responsibility in India. Taylor $\&$ Francis.

Chan, K. M., \& Lai, W. (2018). Foundations in China: From statist to corporatist. American Behavioral Scientist, 62(13), 1803-1821.

Chrisman, J. J., Chua, J. H., Le Breton-Miller, I., Miller, D., \& Steier, L. P. (2018). Governance mechanisms and family firms. Entrepreneurship Theory and Practice, 42(2), 171-186.

Cizakca, M. (1998). A Waqf in history and its implications for modern Islamic economies. Islamic Economic Studies, 6(7), 43-70.

Creswell, J. W. (2013). Qualitative inquiry \& research design. Sage Publications.

Cruz, C., Larraza-Kintana, M., Garcés-Galdeano, L., \& Berrone, P. (2014). Are family firms really more socially responsible? Entrepreneurship Theory and Practice, 38(6), 1295-1316.

Debiki, B. J., Kellermans, F. W., Pearson, A. W., \& Spencer, B. A. (2016). Development of socioemotional wealth importance (SEWi) scale for family firms research. Journal of Family Business Strategy, 7(1), 47-57.

Dieleman, M., \& Koning, J. (2020). Articulating values through identity work: Advancing family business ethics research. Journal of Business Ethics, 163(4), 675-687.

Dubois, A., \& Gadde, L. E. (2002). Systematic combining: An abductive approach to case research. Journal of Business Research, 55(7), 553-560.

Duquette, N. J. (2019). Founders' fortunes and philanthropy: A history of the U.S. charitable-contribution deduction. Business History Review, 93(3), 553-584.

Eisenberg, P. (2005). Challenges for nonprofits and philanthropy: The courage to change. Tufts University Press.

Faber, D. J., \& McCarthy, D. (2005). Introduction. In D. J. Faber \& D. McCarthy (Eds.), Foundations for social change: Critical perspectives on philanthropy and popular movements (pp. 3-32). Rowman \& Littlefield.

Fathallah, R., Sidani, Y., \& Khalil, S. (2020). How religion shapes family business ethical behaviors: An institutional logics perspective. Journal of Business Ethics, 163(4), 647-659.

Feliu, N., \& Botero, I. C. (2016). Philanthropy in family enterprises: A review of literature. Family Business Review, 29(1), 121-141.

Friedman, M. (1970, September 13). The social responsibility of business is to create profits. New York Times Magazine, 122-126.

Ganzin, M., Islam, G., \& Suddaby, R. (2020). Spirituality and entrepreneurship: The role of magical thinking in future-oriented sensemaking. Organization Studies, 41(1), 77-102.

Gao, C., Zuzul, T., Jones, G., \& Khanna, T. (2017). Overcoming institutional voids: A reputation-based view of long-run survival. Strategic Management Journal, 38(11), 2147-2167.

Gardner, J. R. (1992). Oral History and Philanthropy: Private Foundations. The Journal of American History, 79(2), 601-605.

Gautier, A., \& Pache, A. C. (2015). Research on corporate philanthropy: A review and assessment. Journal of Business Ethics, 126(3), 343-369.

Giacomin, V., \& Jones, G. (2021). Spiritual philanthropy in emerging markets. Harvard Business School Working Paper, No. 21-117. Retrieved May 12th, 2021, from https://www.hbs.edu/ris/Publi cation\%20Files/WP21-117_d8d4e428-4065-444f-918d-fb693 79f6df6.pdf.

Giacomin, V., Jones, G., \& Salvaj, E. H. (2019). Business investment in education in emerging markets since the 1960s. Business History. https://doi.org/10.1080/00076791.2019.1675641.
Gioia, D. A., Corley, K. G., \& Hamilton, A. L. (2013). Seeking qualitative rigor in inductive research: Notes on the Gioia methodology. Organizational Research Methods, 16(1), 15-31.

Giridharadas, A. (2018). Winners take all: The elite charade of changing the world. Penguin Random House.

Hackett, C., Grim, B., Stonawski, M., Skirbekk, V., Potančoková, M., \& Abel, G. (2012). The global religious landscape. Pew Research Center.

Hammack, D. C., \& Anheier, H. K. (2010). American foundations: Their roles and contributions to society. Brookings Institution Press.

Harvey, C., Gordon, J., \& Maclean, M. (2021). The ethics of entrepreneurial philanthropy. Journal of Business Ethics, Forthcoming. $171,33-49$

Harvey, C., MacLean, M., Gordon, J., \& Shaw, E. (2011). Andrew Carnegie and the foundations of contemporary entrepreneurial philanthropy. Business History, 53(3), 425-450.

Harvey, C., Yang, R., Mueller, F., \& Maclean, M. (2020). Bourdieu, strategy and the field of power. Critical Perspectives on Accounting, Forthcoming, 73, 102199.

Hay, I., \& Muller, S. (2014). Questioning generosity in the golden age of philanthropy: Towards critical geographies of superphilanthropy. Progress in Human Geography, 38(5), 635-653.

He, L., \& Wang, Q. (2020). Do Chinese corporate foundations enhance civil society? In L. Roza, S. Bethmann, L. Meijs, \& G. von Schnurbein (Eds.), Handbook on corporate foundations (pp. 125-147). Springer Publications.

Hornstein, A. S., \& Zhao, M. (2018). Reaching through the fog: Institutional environment and cross-border giving of corporate foundations. Strategic Management Journal, 39(10), 2666-2690.

Jakwa, T. (2018). The Mo Ibrahim Prize: A misdiagnosis of Africa's problems? Australian Institute of International Affairs, March 6th. Retrieved December 25, 2020, from https://www.internatio nalaffairs.org.au/australianoutlook/mo-ibrahim-prize-misdiagnos is-africas-problems/.

Jamali, D. (2007). The case for strategic corporate social responsibility in developing countries. Business and Society Review, 112(1), $1-27$.

Jamali, D. (2010). The CSR of MNC subsidiaries in developing countries: Global, local, substantive or diluted? Journal of Business Ethics, 93(2), 181-200.

Jamali, D., Lund-Thomsen, P., \& Jeppesen, S. (2017a). SMEs and CSR in developing countries. Business \& Society, 56(1), 11-22.

Jamali, D., Lund-Thomsen, P., \& Khara, N. (2017b). CSR institutionalized myths in developing countries. Business \& Society, 56(3), 454-486.

Jamali, D., \& Mirshak, R. (2007). Corporate social responsibility: Theory and practice in a developing country context. Journal of Business Ethics, 72(3), 243-262.

Jamali, D., \& Sidani, Y. (2011). Is CSR counterproductive in developing countries: The unheard voices of change. Journal of Change Management, 11(1), 69-71.

Jamali, D., Yianni, M., \& Abdallah, H. (2011). Strategic partnerships, social capital and innovation: Accounting for social alliance innovation. Business Ethics: A European Review, 20, 375-391.

Jansons, E. (2015). The business leaders behind the foundations: Understanding India's emerging philanthropists. VOLUNTAS: International Journal of Voluntary and Nonprofit Organizations, 26(3), 984-1006.

Jensen, C. (2013). Foundations and the discourse of philanthropy. Administrative Theory \& Praxis, 35(1), 106-127.

Jones, G., \& Comunale, R. (2018). Business, governments and political risk in South Asia and Latin America since 1970. Australian Economic History Review, 58(3), 233-264. 
Jones, G., \& Comunale, R. (2019). Oral history and the business history of emerging markets. Enterprise \& Society, 20(1), 19-32.

Jung, T., Harrow, J., \& Leat, D. (2018). Mapping philanthropic foundations' characteristics: Towards an international integrative framework of foundation types. Nonprofit and Voluntary Sector Quarterly, 47(5), 893-917.

Kavas, M., Jarzabkowski, P., \& Nigam, A. (2020). Islamic family business: The constitutive role of religion in business. Journal of Business Ethics, 163(4), 689-700.

Kourula, A., \& Delalieux, G. (2016). The micro-level foundations and dynamics of political corporate social responsibility: Hegemony and passive revolution through civil society. Journal of Business Ethics, 135(4), 769-785.

Krasnopolskaya, I. (2020). Corporate foundations in Russia: Overview of the sector. In L. Roza, S. Bethmann, L. Meijs, \& G. von Schnurbein (Eds.), Handbook on corporate foundations (pp. 149-166). Springer Publications.

Krishnan, L. (2005). Concepts of social behavior in India: Daan and distributive justice. Psychological Studies, 50(1), 21-31.

Liket, K., \& Simaens, A. (2015). Battling the devolution in the research on corporate philanthropy. Journal of Business Ethics, 126(2), 285-308.

Long, R. G., \& Mathews, K. M. (2011). Ethics in the family firms: Cohesion through reciprocity and exchange. Business Ethics Quarterly, 21(2), 287-308.

Lumpkin, G. T., \& Brigham, K. H. (2011). Long-term orientation and intertemporal choice in family firms. Entrepreneurship Theory and Practice, 35(6), 1149-1169.

Maclean, M., \& Harvey, C. (2020). Crafting philanthropic identities. In A. D. Brown (Ed.), Oxford handbook of identities in organizations (pp. 637-653). Oxford University Press.

Maclean, M., Harvey, C., \& Clegg, S. (2016). Conceptualizing historical organization studies. Academy of Management Review, 41(4), 609-632.

Maung, M., Miller, D., Tang, Z., \& Xu, X. (2020). Value-enhancing social responsibility: Market reaction to donations by family vs. non-family firms with religious CEOs. Journal of Business Ethics, 163(4), 745-758.

Mayer, C. (2019). Prosperity: Better business makes the greater good. Oxford University Press.

Mcgoey, L. (2012). Philanthrocapitalism and its critics. Poetics, 40(2), 185-199.

Miller, D. C., \& Salkind, N. J. (2002). Four levels of measurement and the statistics appropriate to each level. In D. C. Miller \& N. J. Salkind (Eds.), Handbook of research design \& social measurement (pp. 383-384). Sage Publications.

Mukherjee, K. (2016). CSR approaches of MNEs in developing countries. Journal of Global Responsibility, 7(2), 247-257.

Muthuri, J. N., \& Gilbert, V. (2011). An institutional analysis of corporate social responsibility in Kenya. Journal of Business Ethics, 98(3), 467-483.

Nielsen, W. A. (1972). The big foundations. Columbia University Press.

O'Connor, A. (1996). Community action, urban reform, and the fight against poverty: The ford foundation's gray areas program. Journal of Urban History, 22, 586-625.

O'Toole, J. (2019). The prospects for enlightened corporate leadership. California Management Review, 61(3), 72-92.

Ostrower, F. (1997). Why the wealthy give: The culture of elite philanthropy. Princeton University Press.

Pedrini, M., \& Minciullo, M. (2011). Italian corporate foundations and the challenge of multiple stakeholder interests. Nonprofit Management and Leadership, 22, 173-197.

Phipps, K. A. (2012). Spirituality and strategic leadership: The influence of spiritual beliefs on strategic decision making. Journal of Business Ethics, 106(2), 177-189.
Poole, E. (2009). Organizational spirituality. A literature review. Journal of Business Ethics, 84(4), 577-588.

Prewitt, K., Dogan, M., Heydemann, S., \& Toepler, S. (2006). Legitimacy of philanthropic foundations United States and European perspectives. Russell Sage Foundation.

Quilan, M. K. (2010). The dynamics of interviewing. In D. A. Ritchie (Ed.), The Oxford handbook of oral history (pp. 23-36). Oxford University Press.

Raianu, M. (2016). Tata Philanthropy and the making of modern India, Histphil, February 25th. Retrieved December 25, 2020, from https://histphil.org/2016/02/25/tataphilan thropy-and-the-making-of-modern-india/.

Reilly, T., Saini, A., \& Skiba, J. (2020). Ethical purchasing dissonance: Antecedents and coping behaviors. Journal of Business Ethics, 163(3), 577-597.

Rey-Garcia, M., Layton, M. D., \& Martin-Cavanna, J. (2020). Corporate foundations in Latin America. In L. Roza, S. Bethmann, L. Meijs, \& G. von Schnurbein (Eds.), Handbook on corporate foundations (pp. 167-190). Springer Publications.

Ritchie, D. A. (Ed.). (2010). The Oxford handbook of oral history. Oxford University Press.

Roelofs, J. (2007). Foundations and collaboration. Critical Sociology, $33,479-504$

Roelofs, J. (2015). How foundations exercise power. American Journal of Economics and Sociology, 74(4), 654-675.

Rojas, C., \& Morales, G. (2005). Private contributions to the public sphere: Corporate foundations in Colombia. In C. Sanborn \& F. Portocarrero (Eds.), Philanthropy and social change in Latin America (pp. 163-189). Harvard University Press.

Roza, L., Bethmann, S., Meijs, L., \& von Schnurbein, G. (Eds.). (2020). Handbook on corporate foundations. Springer Publications.

Salvato, C., \& Corbetta, G. (2013). Transitional leadership of advisors as a facilitator of successors' leadership construction. Family Business Review, 26(3), 235-255.

Sanborn, C., \& Portocarrero, F. (2005). Philanthropy and social change in Latin America. Harvard University Press.

Schuyt, T. N., Gouwenberg, B. M., \& Hoolwerf, B. L. (2018). Foundations in the Netherlands: Toward a diversified social model? American Behavioral Scientist, 62(13), 1833-1843.

Sharma, P., \& Sharma, S. (2019). Patient capital: The role of family firms in sustainable business. Cambridge University Press.

Shaw, E., Gordon, J., Harvey, C., \& Maclean, M. (2013). Exploring contemporary entrepreneurial philanthropy. International Small Business Journal, 31(5), 580-599.

Shirodkar, V., Beddewela, E., \& Richter, U. H. (2018). Firm-level determinants of political CSR in emerging economies: Evidence from India. Journal of Business Ethics, 148(3), 673-688.

Strauss, A., \& Corbin, J. (1994). Grounded theory methodology. Handbook of Qualitative Research, 17(1), 273-285.

Sundar, P. (2013). Business and community: The story of corporate social responsibility in India. Sage Publications.

Sundar, P. (2017). Giving with a thousand hands: The changing face of Indian philanthropy. Oxford University Press.

Thumala Olave, M. A. (2007). Notions of evil, the devil and sin among Chilean businessmen. Social Compass, 54(4), 613-632.

Toepler, S. (2018). Toward a comparative understanding of foundations. American Behavioral Scientist, 62(13), 1956-1971.

Turitz, S., \& Winder, D. (2005). Private resources for public ends: Grantmakers in Brazil, Ecuador, and Mexico. In C. Sanborn \& F. Portocarrero (Eds.), Philanthropy and social change in Latin America (pp. 255-284). Harvard University Press.

United Nations Development Programme (UNDP). (2016). Philanthropy as an emerging contributor to development cooperation. Retrieved March 10, 2021, from https://www.undp.org/content/ undp/en/home/librarypage/corporate/philanthropy-as-an-emerg ing-contributor-to-development-cooperati.html. 
Van Cranenburgh, K. C., \& Arenas, D. (2014). Strategic and moral dilemmas of corporate philanthropy in developing countries: Heineken in Sub-Saharan Africa. Journal of Business Ethics, 122(3), 523-536.

Van Slyck, A. A. (1995). Free to all: Carnegie libraries and American culture, 1890-1920. University of Chicago Press.

Wadhwani, R. D., Kirsch, D., Welter, F., Gartner, W. B., \& Jones, G. (2020). Context, time, and change: Historical approaches to entrepreneurship research. Strategic Entrepreneurship Journal, 14(1), 3-19.

Werbel, J. D., \& Carter, S. M. (2002). The CEO's influence on corporate foundations giving. Journal of Business Ethics, 40(1), $47-60$.

Westhues, M., \& Einwiller, S. (2006). Corporate foundations: Their role for corporate social responsibility. Corporate Reputation Review, 9(2), 144-153.

WINGS Global Philanthropy Report. (2018). The global landscape of philanthropy. Retrieved March 10, 2021, from https://wings.issue lab.org/resources/29534/29534.pdf.

Worden, S. (2003). The role of religious and nationalist ethics in strategic leadership: The case of JN tata. Journal of Business Ethics, 47(2), 147-164.

World Bank. (2007). International Finance Briefing Note 33, February 27, 2007. Retrieved March 10, 2021, from http://documents1. worldbank.org/curated/en/696301468313503152/pdf/43273 0NEWS0Box1LIC10IFBriefingNote3.pdf.
Wren, D. A. (1983). American business philanthropy and higher education in the nineteenth century. Business History Review, 57, $321-346$.

Yates, J. (2014). Understanding historical methods in organization studies. In R. Daniel Wadhwani \& Marcelo Bucheli (Eds.), Organizations in time: History, theory, methods (pp. 265-283). Oxford University Press.

Young, N., \& Shih, J. (2004). Philanthropic links between the Chinese Diaspora and the People's Republic of China. In L. C. Chen, P. F. Geithner, \& P. D. Johnson (Eds.), Diaspora philanthropy and equitable development in China and India (pp. 129-175). Global Equity Initiative Asia Center.

Yusof, M., Mohd Nor, L., \& Edward Hoopes, J. (2014). Virtuous CSR: An Islamic family business in Malaysia. Journal of Family Business Management, 4(2), 133-148.

Zhao, M. (2012). CSR-based political legitimacy strategy: Managing the state by doing good in China and Russia. Journal of Business Ethics, 111(4), 439-460.

Zunz, O. (2014). Philanthropy in America. Princeton University Press.

Publisher's Note Springer Nature remains neutral with regard to jurisdictional claims in published maps and institutional affiliations. 